
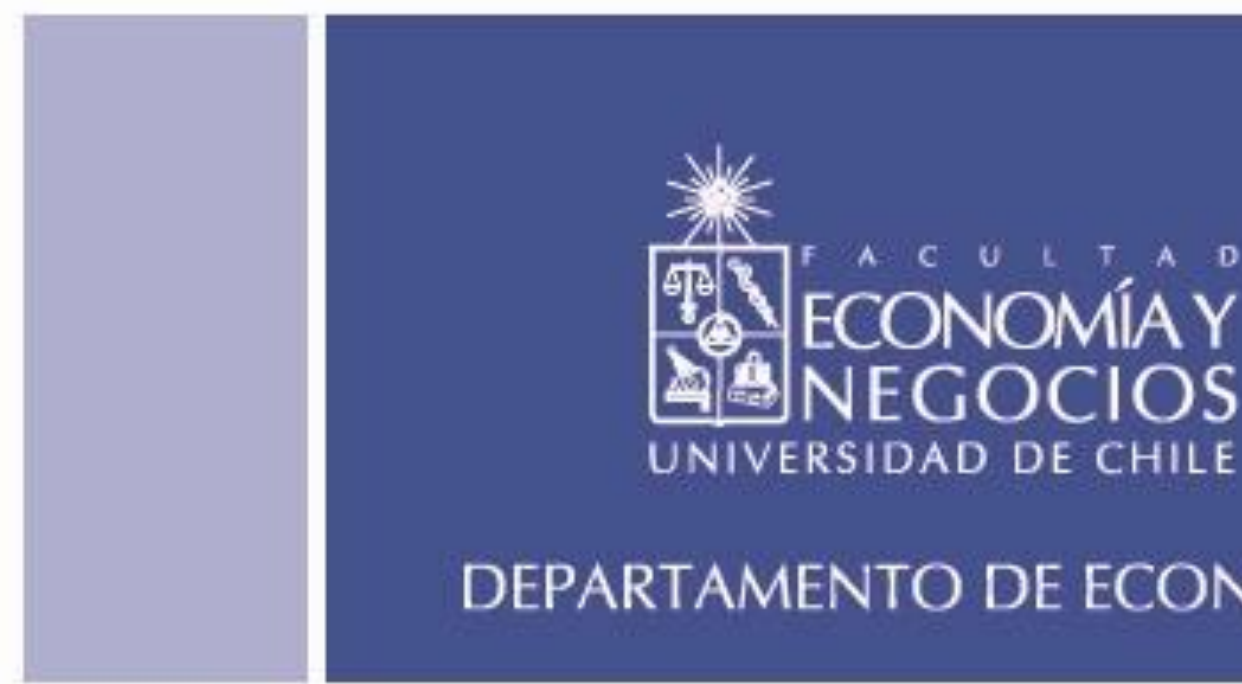

DEPARTAMENTO DE ECONOMÍA

\title{
DO TAX CUTS ENCOURAGE RENT-SEEKING BY TOP CORPORATE EXECUTIVES? THEORY AND EVIDENCE
}

Autores: Dana Andersen y Ramón López

Santiago, Agosto de 2012

La serie de Documentos de Trabajo (SDT) del Departamento de Economía de la Universidad de Chile en versión PDF puede descargarse en la dirección electrónica www.econ.uchile.cl/SDT . Para contactar al editor ejecutivo de SDT remitirse a sdt@econ.uchile.cl 


\title{
Do Tax Cuts Encourage Rent-Seeking by Top Corporate Executives? Theory and Evidence ${ }^{1}$
}

\author{
Dana Andersen and Ramón López²
}

August 5, 2012

\begin{abstract}
This paper seeks to understand the role of tax policy in executive rent-seeking within the firm and income. While a longstanding literature maintains that executives are afforded discretion in obtaining rents, that the degree of exercising this discretion is influenced by tax policy is, however, not considered in the analysis of tax policy. We propose a simple model of executive pay, where executive effort (all value-creating activities) and rent-seeking (all value-diverting activities) are determined endogenously. The model shows that, under some conditions, rent-seeking, as well as effort, responds to changes in marginal tax rates. Moreover, (1) a positive association between the elasticity of taxable income with respect to the tax policy and the degree in which the internal institutions of the firm favor executives vis-à-vis shareholders, and (2) a negative association between the elasticity of taxable income and the executive's equity-at-stake, are manifestations of tax policy influencing rent-seeking. We empirically test these implications and find results that are consistent with the predictions of the model.
\end{abstract}

\section{Introduction}

This paper seeks to understand the role of tax policy in shaping executives' incentives for adding value to and rent-seeking from their firms and their consequent incomes. A prerequisite, of course, is an understanding of the fundamentals governing the pay-setting process, which are intensely debated (Frydman and Jenter, 2010). Implicit in the standard analysis of tax policy is that executive compensation is chosen to maximize shareholder value subject to various constraints. Under this assumption, it follows that " all (emphasis theirs) responses to taxation are symptomatic of deadweight loss" (Saez, et al., 2012). If, however, executives are afforded the opportunity to obtain rents, as maintained by a "well-established" (Edlin and Stiglitz, 1995) literature of managerial theories of the firm then it follows that, under

\footnotetext{
${ }^{1}$ Preliminary draft, comments welcome. Please do not cite.

${ }^{2}$ Andersen: University of Maryland, College Park. Email: dandersen@arec.umd.edu. López: University of Maryland, College Park and University of Chile. Email: rlopez@arec.umd.edu
} 
certain conditions, the degree in which this discretion is exercised is subject to incentives shaped by tax policy. Taxes, in this case, would actually discourage, rather than engender, responses entailing deadweight costs.

That executives rent-seek is, of course, not an original insight--the observation dates back to at least Frank Knight (1921) who described the "internal problems of the corporation", which include the "predatory propensities" of its constituents. ${ }^{3}$ The standard contemporary framework for executive compensation assumes that contracts, designed by the board of directors on behalf of shareholders, maximize firm value subject to informational asymmetries regarding the executive's ability and effort and various other contractible constraints. That is, pay is efficient. ${ }^{4}$ A longstanding literature, however, emphasizes a number of market failures precluding efficient contracts, including executive under-investment in firm-specific human capital (Edlin and Reichelstein, 1996), over-investment in projects that the incumbent executive is particularly skilled at managing (Vishny and Shleifer, 1989), and over-investment in projects that the incumbent executive has an informational advantage over (Edlin and Stiglitz, 1995). More recent interpretations posit that the pay-setting process resembles a "managerial optimal" framework, where executives set their own pay subject to costs associated with shareholder and peer "outrage" (Bechuk and Fried, 2004) or costs associated with an increased likelihood of replacement (Kuhnen and Zwiebel, 2008; Ruiz-Verdú, 2008 ). If indeed accurate, a natural question to consider is whether tax policy influences executives' propensity for rent-seeking? And, if so, under what conditions and to what extent? Such questions have not been considered in the analysis of tax policy and, while this paper certainly cannot answer all of these questions categorically, it aims to at least shed some light on each.

The theoretical analysis of optimal tax policy, pioneered by Mirrlees (1971), postulates that maximizing social welfare entails designing tax policy such that high-ability taxpayers have sufficient incentives to produce at high levels (thereby, revealing their high-ability type). The

\footnotetext{
${ }^{3}$ From Risk, Uncertainty, and Profit (1921), Section III.VIII.31.

${ }^{4}$ The classic studies are Mirrlees (1976), Jensen and Meckling (1976), Jensen (1986), Holmstrom (1979), Grossman and Hart (1983), and others. For surveys, we refer to Murphy (1999), Prendergast, (1999), and Frydman (2010).
} 
well-known zero top marginal tax rate follows. ${ }^{5}$ While often discounted in practice due to normative concerns or administrative complexity (e.g., keeping track of numerous incentive compatibility constraints), the fundamental assumption that taxes discourage effort (value creating activities), thereby, generating efficiency costs (or excess burden), is taken for granted in the analysis of tax policy. ${ }^{6}$ Moreover, the view that marginal tax rates should be zero, or at least non-increasing at the top, is not merely a theoretical curiosity--studies using estimated elasticities of taxable income and empirical simulations conclude that marginal tax rates should be declining in income (Tuomala, 1990; Gruber and Saez, 2002; Mankiw, Weinzierl, and Yagan, 2009); again, taking for granted that taxes discourage effort. This paper questions not whether taxes discourage effort, but whether taxes discourage only effort. Particularly taxation of executives, whom are afforded the opportunity to obtain rents, might entail a net efficiency cost much lower than previously understood; or possibly negative under certain conditions.

This paper is, therefore, related to a number of papers exploring various behavioral responses to taxation. While early studies focused on traditional measures of labor supply, which are mostly insensitive to tax policy (Heckman 1993), Feldstein $(1995,1999)$ broadened the scope of behavioral responses, including shifting income (over time and between different tax bases, including non-taxable ones), changing effort and investment in human capital, and tax avoidance and evasion. The present paper is the only one, however, to explore behavioral responses entailing negative social costs. ${ }^{7}$

We propose a simple model of executive compensation, demonstrating that, under plausible conditions, tax policy influences not only effort but also rent-seeking. Similar to models emphasizing managerial-specific investments (Shleifer and Vishny, 1989; Edlin and Stiglitz, 1995) and managerial optimal frameworks (Kuhnen and Zwiebel, 2008; Ruiz-Verdú, 2008), executives are afforded discretion in obtaining rents from shareholders as a consequence of market frictions circumscribing the ability of shareholders to remove an

\footnotetext{
${ }^{5}$ The intuition for the result is that if the top income-earner earned $x$ dollars and faced a strictly positive marginal tax rate then setting the marginal tax rate for income beyond $x$ at zero will not decrease tax revenue and may induce greater productive effort.

${ }^{6}$ For example, Martin Feldstein (2006) writes: “The good news is that marginal tax rates are lower today than they were in the past and that the deadweight losses of the tax system are therefore correspondingly lower."

${ }^{7}$ One exception is Chetty (2009), who emphasizes a number of positive externalities associated with charitable giving or tax “sheltering" behaviors (e.g., employing lawyers), which increase as tax rates increase.
} 
incumbent executive. From a modeling point of view, this entails imposing a cost to shareholders associated with replacing an existing executive, thereby, affording the executive rents (income in excess of shareholders' frictionless opportunity cost). Unlike existing models, however, we incorporate the marginal income tax rate, which determines the executive's optimal rents and effort. The main insight of the model is, therefore, that both effort and rentseeking respond to changes in tax policy. Moreover, the model predicts that the response of rent-seeking to changes in the net-of-tax rate (1 minus the marginal tax rate) is positively associated with the degree in which the internal institutions of the firm favor executives ("proexecutive" institutions) and the executive's equity-at-stake.

The empirical analysis uses executive compensation data for the top five paid executives in S\&P 1500 companies from the Execucomp database for the period 1992 to 2005 . We focus primarily on the empirical hypothesis that executives at firms with institutions favoring executives exhibit greater income sensitivity to changes in the net-of-tax rate compared to executives at firms with institutions favoring shareholders. We employ a well-known index of corporate governance--the so-called 'E index' proposed by Bebchuk, Cohen, and Ferrell (2008)-as variation in the the degree in which institutions of the firm favor executives vis-à-vis shareholders. Similarly, we test other predictions of the model using variation in the executive's equity-at-stake, which is defined as the change in executive wealth from all stocks and unexercised stock options held from a change in firm value.We follow a similar empirical strategy as Goolsbee (2000) and Frydman and Molloy (2011) to examine the elasticity of taxable income with respect to the net-of-tax rate, allowing the elasticity of taxable income to depend on the variables mentioned above. ${ }^{8}$ Consistent with the prediction of the model, we find that the elasticity of taxable income is strongly associated with the internal institutions of the firm. In particular, executives at firms with pro-executive institutions have significantly higher short-run elasticities (contemporaneous effect) of taxable income, while the anticipatory

${ }^{8}$ The elasticity of taxable income with respect to the net-of-tax rate is defined as $\frac{\partial y}{\partial(1-\tau)} \frac{(1-\tau)}{y}$ where $y$ is taxable income and $\tau$ is the marginal tax rate. At times, for brevity, we will abbreviate the elasticity of taxable income with respect to the net-of-tax rate as, simply, the elasticity of income. 
elasticity indicates very little variation. ${ }^{9}$ Thus, the long-run elasticity of income is significantly higher for executives at firm with pro-executive institutions: the estimated long-run elasticity of executives at firms with institutions most favorable to shareholders is statistically insignificant, whereas executives at firms with institutions most favorable executives is large (point estimates are between 0.8 and 0.9 ) and statistically significant. ${ }^{10}$

\section{Model}

In this section, we propose a simple model of executive income given both endogenous effort and rent-seeking. The purpose of the model is to demonstrate one possible pay-setting framework such that changes in the net-of-tax rate elicit rent-seeking and to generate testable hypotheses. For terminology, we refer to the opportunity cost associated with replacing the incumbent executive as "entrenchment", whereas "rent-seeking" refers to income afforded as a consequence of entrenchment. We refer to the additional value added to the firm by the executive as "effort". Finally, we refer to the costs to the executive of imposing entrenchment and supplying effort as, simply, the cost of entrenchment and effort.

\subsection{Set-up}

Consider a firm comprised of a representative shareholder ${ }^{11}$ and representative (incumbent) executive. The return to the shareholder for a given unit of time, is given by

$$
r=q-w+\eta
$$

where $q$ represents effort, $w$ represents executive income, and $\eta$ represents a random variable (noise) $\eta: F($ ). Prior to the realization of $\eta$, the executive chooses his (ex-ante)

\footnotetext{
${ }^{9}$ The anticipatory elasticity accounts for income shifting and is defined as the effect of the tax rate in period $t+1$ on income in period $t$.

${ }^{10}$ Similar studies, which do not account for the heterogeneity explored in this paper, typically find insignificant or modest effects. Goolsbee (2000) and Hall and Liebman (2000) estimate that that the long-run elasticity is at most 0.4 (the former using the Clinton tax hikes (OBRA 93) and the latter using the tax cuts of the 80s as well as OBRA 93), whereas Nada and Giertz (2006) estimate an elasticity roughly half that size (using OBRA 93 as well as the Bush tax cuts). Finally, using a sample of top executives in large firms from 1946 to 2005, Frydman and Molloy (2011) find that the elasticity is not significantly different from zero.

11 "Shareholder" is emblematic of the executive's relevant bargaining partner, which is typically assumed to be the board of directors but also includes, rival executives, acquiring companies, corporate raiders, etc.
} 
level of effort, entrenchment, and compensation, and is fired (ex-post) if the realized return to the shareholder plus entrenchment is less than the "outside" realized return plus entrenchment. ${ }^{12}$ That is, the executive is fired if (ex-post)

$$
q-w+\theta+\eta \leq q \sigma w o+\theta q q
$$

where $\theta$ represents entrenchment and tilde denotes variables of the outside firm. Without loss of generality, we set $\tilde{\eta}=0$. Therefore, the probability of the event that the incumbent executive is fired (per unit of time) can be represented as

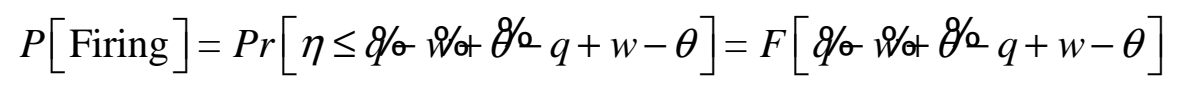

As expected, the probability that the executive is fired is decreasing in effort and entrenchment but increasing in his income.

We assume the executive owns a fixed fraction of shares $\mu$, and refer to $\mu$ as his equity-at-stake and $\mu r$ as the his return on equity. ${ }^{13}$ Let's suppose, without qualification for the moment, that the cost of effort and the cost of entrenchment are represented by the functions $\hat{e}(q ; \cdot)$ and $\hat{c}(\theta ; \cdot)$. We assume the executive is risk-neutral, infinitely-lived, and has a pure rate of time preference $\rho$. The employed executive therefore maximizes the expected present discounted value of lifetime utility given by

$$
V=E \int_{0}^{\infty} \exp (-\rho t)[(1-\tau)(w+\mu r)-\hat{e}(q ; \cdot)-\hat{c}(\theta ; \cdot)] d t
$$

where $\tau$ represents the marginal income tax rate and $(1-\tau)$ represents the so-called net-oftax rate. We assume the utility of an unemployed executive is independent of the executive's

\footnotetext{
${ }^{12}$ The outside realized return might refer to the mean realized return of similar industries, but there is no loss in generality in considering a single "outside" firm.

${ }^{13}$ Equity at stake is a reflection of options and restricted stock granted in the previous period and therefore is predetermined in the short-run. Equity at stake can be considered more generally as his pay-for-performance, including various components of pay tied directly to the market value of the firm.
} 
current decisions and is represented by $V^{u} \cdot{ }^{14}$ Using the maximum principle, the employed executive chooses his compensation, effort, and entrenchment to maximize the value of employment $^{15}$

$$
V^{E}=\max _{w, q, \theta}\left\{\frac{(1-\tau)(w+\mu r)-\hat{e}(q ; \cdot)-\hat{c}(\theta ; \cdot)+F[\cdot] V^{u}}{\rho+F[\cdot]}\right\}
$$

\subsection{Assumptions}

Suppose effort and rent-seeking exhibit the following technologies

$$
\theta \equiv A(g) y(\mathbf{x}) \quad \text { and } \quad q \equiv B(g) z(\mathbf{v})
$$

where $g$ represents the internal institutions of the firm and $\mathbf{X}$ and $\mathbf{v}$ represent vectors of effort and entrenchment inputs, respectively. ${ }^{16}$ The parameters $A(g)$ and $B(g)$ represent total factor productivity. Let's suppose that $g$ is increasing (decreasing) in the degree in which institutions promote (restrict) shareholder rights. We assume the functions $y$ and $z$ are: ( $A 1$ ) monotonically increasing, ( $A 2)$ twice continuously differentiable, and ( $A 3$ ) homogenous of degree less than one. Moreover, we assume the following

\footnotetext{
${ }^{14} \mathrm{We}$ do not, however, preclude the possibility that $V^{u}$ is changing over time or with respect to the equilibrium choices of all executives.

${ }^{15}$ To derive (5), recall $F$ is the probability of being fired per unit of time, hence $t F$ is the probability of being fired over an arbitrary interval $[0, t]$. Thus, expected present discounted value of utility for an employed executive over an interval $[0, t]$ is given by $V^{E}=t[(1-\tau)(w+\mu r)-\ddot{\Theta}(q ;)-\ddot{\alpha}(\theta ; \cdot)]+e^{-\rho t}\left(t F V^{u}+(1-t F) V^{E}\right)$. Taking the limit as $t \rightarrow 0$ and noticing that $\lim _{t \rightarrow 0} e^{-\rho t}=(1-\rho t)$ implies expression (5).

${ }^{16}$ Because exerting effort and rent-seeking are qualitatively disparate tasks (or equivalently, employ disparate inputs), we have presumed that the cost of effort and the cost of entrenchment are independent. This assumption simplifies the analysis considerably and is a close approximation. For example, the costs associated with effort include the number of hours worked (foregone leisure), mental effort, and the acquisition of skills, whereas the costs associated with rent-seeking include the social and legal costs associated with self-dealing, weakening shareholder rights, and transgressing social norms (Piketty and Saez, 2003).
} 


$$
\text { A4. } f^{\prime}(\cdot)>0 \quad A 5 \cdot A^{\prime}(g)<0 \quad A 6 \cdot B^{\prime}(g) \geq 0
$$

where prime denotes derivatives and $f^{\prime}(\cdot)$ is evaluated at the executives optimal choice set (the marginal probability that the executive is fired is increasing at the optimal level of income, effort, and entrenchment). Assumption $A 5$ implies that pro-shareholder institutions diminish the productivity of entrenchment inputs, whereas $A 6$ implies that the pro-executive institutions do not enhance the productivity of effort inputs. Several results follow almost immediately from (??) and $\mathrm{A} 1$ to $A 6 .^{17}$

$$
\begin{array}{clll}
R 1 . \hat{c}(\theta)=a(g) c(\theta) & R 2 . \hat{e}(q)=b(g) e(q) & R 3 . a^{\prime}(g)>0 & R 4 . b^{\prime}(g)<0 \\
R 5 . c^{\prime}(\theta)>0 & R 6 . c^{\prime \prime}(\theta)>0 & R 7 . e^{\prime}(q)>0 & R 8 . e^{\prime \prime}(q)>0
\end{array}
$$

where $a(g)$ and $b(g)$ are monotonic transformations of $A(g)$ and $B(g)$.

\subsection{Baseline Analysis}

The optimality conditions are quite simple and can be deduced intuitively, without resorting to any computation (the Appendix, however, contains a formal derivation). The executive chooses his current flow of benefits (after tax income plus return on equity less the costs of effort and entrenchment) and the probability of being fired; thus, he faces a dual problem. Reducing income, increasing effort, and increasing entrenchment are costly actions to reduce the probability of being fired. The executive's dual problem, therefore, is to minimize the cost of these actions subject to an optimal probability of being fired. Cost minimization implies that the net marginal cost of reducing income (after taxes and after accounting for the effect on his return on equity) should equal the net marginal cost of effort and entrenchment, otherwise there is a corner solution.

\footnotetext{
${ }^{17}$ For example, if $y$ is a homogenous function of degree $1 / \gamma<1$ then the corresponding cost function can be represented as $C(\theta, g, \mathbf{p})=,m(\mathbf{p})\left(\frac{\theta}{A(g)}\right)^{\gamma}$ where $m(\mathbf{p})$ is a per-unit cost function of a vector of factor prices p. Thus, expressing $a(g) \equiv A(g)^{-\gamma}$ and treating factor prices as fixed yields $R 1, R 3, R 5$, and $R 6$. The other results are similar.
} 
Expressing the above mathematically, the net marginal cost of reducing income is equal to $(1-\tau)$ less the net marginal return on equity $\mu(1-\tau)$. Thus, the net marginal cost of reducing income is equal to $(1-\tau)(1-\mu)$. The net marginal cost of effort is equal to the marginal cost of effort $b(g) e^{\prime}(q)$ plus the net marginal return on equity $\mu(1-\tau)$. Finally, the net marginal cost of entrenchment is equal to $a(g) c^{\prime}(\theta)$ (entrenchment reduces returns only insofar as it allows greater compensation). Thus, an interior solution implies $b(g) e^{\prime}(q)=(1-\tau)$ and $a(g) c^{\prime}(\theta)=(1-\tau)(1-\mu)$. We highlight several consequences.

\section{Result 1: The Behavioral Responses to Changes in the Net-of-Tax Rate}

Both executive effort and rent-seeking are increasing in the net-of-tax rate. In particular, the behavioral responses to changes in the net-of-tax rate are described by

$$
\frac{d q^{*}}{d(1-\tau)}=\frac{1}{b(g) e^{\prime \prime}(q)}>0 \quad \text { and } \quad \frac{d \theta^{*}}{d(1-\tau)}=\frac{1-\mu}{a(g) c^{\prime \prime}(\theta)}>0
$$

Proof: Follows from the optimality conditions and the envelope theorem.

Result 1 demonstrates the negative efficiency costs (or efficiency gains) of taxation associated with rent-seeking, as well as the usual efficiency costs associated with discouraging effort. The former is a consequence of the distortion engendered by diverting factors of production towards rent-seeking rather than towards creating new value. Result 1 also demonstrates that pro-shareholder institutions increase the response of effort and decrease the response of rent-seeking to changes in the net-of-tax rate.

The first-order conditions imply that the executive's optimal income is determined by the equilibrium effort and entrenchment. That is, income can be characterized as

$w^{*}(\tau)=w(q(\tau), \theta(\tau))$. Thus, the effect of changes in the net-of-tax rate on income is given by

$$
\frac{d w}{d(1-\tau)}=\frac{\partial w}{\partial q} \frac{d q}{d(1-\tau)}+\frac{\partial w}{\partial \theta} \frac{d \theta}{d(1-\tau)}
$$


Moreover, the following lemma follows

\section{Lemma 1: The Effect of Taxes on the Probability of Firing}

Tax rates do not change the probability that the executive is fired because income is completely "offset" by changes in effort and entrenchment.

Proof: The first-order conditions and the envelope theorem imply that $\partial w / \partial q=\partial w / \partial \theta=1$.

Lemma 1 implies that the probability of being fired is invariant with net-of-tax rate, which implies that $w-q+\theta=\psi$, where $\psi$ is a fixed parameter. Similarly, the probability that the outside executive is fired is also fixed, implying that $\tilde{w}-\tilde{q}+\tilde{\theta}=\tilde{\psi}$, where $\tilde{\psi}$ is a fixed parameter. Therefore, treating $\tilde{\psi}$ as fixed entails no loss of generality for the analysis of tax policy.

\section{Result 2: The Response of Income with Respect to the Net-of-Tax Rate}

The response of income with respect to the net-of-tax rate corresponds to the net effect of the changes in effort and entrenchment. In particular

$$
\frac{d w}{d(1-\tau)}=\frac{1}{b(g) e^{\prime \prime}(q)}+\frac{1-\mu}{a(g) c^{\prime \prime}(\theta)}>0
$$

Proof: Follows from Result 1 and (8).

\section{Corollary 1: Firm Institutions and the Response of Income with Respect to the Net-of-Tax Rate}

The relationship between firm institutions and the response of income with respect to the netof-tax rate is ambiguous. On the one hand, pro-shareholder institutions are positively related to the response of income derived from increased effort. On the other hand, pro-shareholder institutions are negatively related to the response of income derived from increased entrenchment.

\section{Corollary 2: Equity-at-stake and the Response of Income with Respect to the Net-of-Tax Rate}

Equity ownership is negatively associated with the response of income with respect to the netof-tax rate.

Corollaries 1 and 2 represent the primary empirical hypotheses of the model, which we discuss in greater detail in the next section and in the empirical analysis. 


\subsection{Summary and Empirical Hypotheses}

Result 1 demonstrates that the response of rent-seeking to changes in the net-of-tax rate is positively associated with pro-executive institutions, whereas the response of effort is negatively associated with such institutions. The net effect of institutions on the response of income with respect to the net-of-tax rate is, therefore, ambiguous. Moreover, the executive's equity-at-stake is negatively associated with the response of rent-seeking and therefore negatively associated with the response of income.

Because it cannot be empirically determined whether changes in executive income represent changes in effort or rent-seeking, the proposition that rent-seeking represents an important response to changes in the net-of-tax rate is, admittedly, difficult to empirically verify. However, the model demonstrates that a positive association between pro-executive institutions and the response of income to changes in the net-of-tax rate is evidence that rentseeking is an important behavioral response. In fact, it implies that the response of rent-seeking dominates the response of effort, given that the cost of effort is negatively associated with proexecutive institutions. Similarly, a positive association between equity-at-stake and the response of income to changes in the net-of-tax rate is evidence of rent-seeking according to the model. In the following section, we empirically show that, in fact, pro-executive institutions and less equity-at-stake tend to be associated with greater responses to changes in the net-oftax rate. Such evidence is suggestive, but of course not definitive, without further consideration of alternative explanations, which we discuss after presenting the empirical results.

\section{Empirical Analysis}

\subsection{Data Sources}

The U.S. Securities and Exchange Commission (SEC) requires publicly traded companies to disclose the compensation of their five highest-paid employees. The data are kept by Standard and Poor's Execucomp database for S\&P 500, S\&P Mid Cap 400, and S\&P Small Cap 600 companies, and recorded from the corporations' proxy statements and $10-\mathrm{K}$ forms. The Execucomp data span from 1992 to 2011 and include detailed compensation panel data. Also, 
Compustat North America, which includes the Execucomp database, contains various firm-level financial variables. These data have been employed in nearly all related empirical studies; see Goolsbee (2000) for a more detailed discussion of the dataset.

We also employ firm-level corporate governance data compiled by the Investor Responsibility Research Center (IRCC) and provided by Riskmetrics. The IRCC Takeover Defense database has been used to construct several corporate governance indicators, the most wellknown being the so-called "Governance Index" or (henceforth, GIM Index) by Gompers, Metrick, and Ishii (2003) and the "Entrenchment Index" (henceforth, E Index) by Bebchuk, Cohen, and Ferrell (2008), the later refined the former twenty-four provisions composing the GIM Index to six key indicators. ${ }^{18}$ We focus primarily, but not exclusively, on the $E$ Index because, as discussed by the authors, several provisions are superfluous. ${ }^{19}$ The data span from 1990 to 2006 for 1500 large firms, ${ }^{20}$ which is a slightly smaller universe than the Compustat dataset. Also related to corporate governance are characteristics of the board of directors, which are detailed in Riskmetrics Historical Directors data; and features of institutional ownership, which are provided by Thomson Reuters. Finally, we use the TAXSIM Model to simulate maximum marginal tax rates across states and across time, accounting for the combined effect of federal and state taxes. We discuss all of the aforementioned data in more detail below.

\subsection{Tax Policy and Accounting for Tax Rates}

From 1993 to 2003, a number of federal tax acts increased, and then decreased, marginal tax rates, along with changes at the state level, which can be used to identify the elasticity of taxable income. We briefly recount the major changes in the federal tax code. The Omnibus Budget Reconciliation Act of 1993 raised the top marginal income tax rate (for married, joint filers with taxable income greater than $\$ 250,000)$ from 31 percent to 39.6 percent. The

\footnotetext{
${ }^{18}$ Because the provisions included in the E Index and GIM Index are not randomly assigned, we cannot make strong claims of causality based on the empirical relationships alone. Gompers, Ishi, and Metrick (2003) argue that because the particular provisions do not change significantly over time, they might be considered predetermined.

${ }^{19}$ This index has been used extensively (over 158 studies available on SSRN). A list of papers employing this index can be found at: http://www.law.harvard.edu/faculty/bebchuk/studies.shtml

${ }^{20}$ More precisely, the data cover S\&P 500 as well as the annual lists of the largest corporations published in Fortune, Forbes, and Businessweek.
} 
Economic Growth and Tax Relief Reconciliation Act of 2001 contained a number of tax provisions that were phased in over several years. Many of the tax reductions were designed to be to be enacted over the course of up to 9 years; however, the the Jobs and Growth Tax Relief Reconciliation Act of 2003 accelerated the reductions for 2004 and 2006, which were retroactively enacted to apply to the 2003 tax year. On July 1, 2001 and January 1, 2002, the year 2000 income rates $(28,31,36$, and 39.6 percent) were reduced by 0.5 percentage points, reducing each rate by 1 percentage point. More reductions were scheduled for the beginning of 2004 and 2006, reducing the top rate by an additional 2.6 percentage points and the next three rates by an additional 2 percentage points. The 2003 tax cut accelerated these reductions, thereby, lowering the rates to $25,28,33$, and 35 percent, which were effective for 2003 tax year. All of the reduced rates have been in effect until 2012.

One of the drawbacks of using the Execucomp database, rather than tax return data, is that we cannot observe all components of total taxable income, including capital gains income, income of the spouse, and tax deductions. We follow the conventional approach in calculating earned income, which assumes that all executives are married and file joint income tax returns, and have no household income outside the firm. While several, or even most, studies rely on variation in federal marginal tax rates (Goolsbee, 2000; Frydman and Molloy, 2011), we follow several more recent studies using variation in state tax rates, as well as federal rates (Nada and Giertz, 2006; Katuš Č ák, 2009), using the TAXSIM Model simulator. To circumvent the problem of endogenous tax rates for individuals around the tax bracket cutoffs, we follow previous studies (Goolsbee, 2000; Nada and Giertz, 2006) that exclude executives with permanent income below the top-bracket, where permanent income is defined as the mean income in the sample. ${ }^{21}$ In particular, we follow Nada and Giertz (2006) and exclude executives whom have permanent income less than $\$ 400,000$ (in 2006 dollars). ${ }^{22}$

\subsection{Executive Compensation and Firm Data}

\footnotetext{
${ }^{21}$ Of course, permanent income might also be endogenous and limiting the sample might bias the results. For consistency with the literature and to maintain the focus of the paper, we rely on Goolsbee (2000), who addresses these issues and finds that the results are insensitive to various cutoffs and tax rate definitions.

${ }^{22}$ Nada and Giertz (2006) claim to use the same cutoff (after adjusting for inflation) as Goolsbee (2000), using $\$ 376,000$ in $2004 \$$, which is roughly $\$ 399,000$ in $2006 \$$.
} 
We focus on taxable income, which is comprised of the following components: salary, bonus, options exercised (ISOs and NQSOs), long-term incentive payouts (LTIP), and restricted stock grants. We also disaggregate taxable income and look at the effect of tax rates on salary and bonus and options exercised separately, as well the effect on compensation including nontaxable income. In general, all forms of taxable income are taxed at the personal earned income tax rate, except for Incentive Stock Options (ISOs), which are taxed at the capital gains rate upon sale. ISOs, unlike Nonqualified Stock Options (NQSOs), are not deductible against corporate profits and have an annual cap of $\$ 100,000$ per-executive and, therefore, represent roughly 5 percent of options exercised. As conventional, we assume all options exercised are NQSOs. (See Hall and Liebman (2000) for a detailed discussion of the taxation of executive compensation.) Following Frydman and Molloy (2011), we control for firm-specific variables including market value, sales, leverage, and market-to-book ratio. To properly account for firmlevel data and tax rates, it is necessary to omit firms with fiscal years straddling more than one year (i.e., firms with fiscal years not ending in December), which excludes about 40 percent of the observations. ${ }^{23}$

In addition to the usual set of controls employed in estimating the elasticity of taxable income, we also account for the degree in which the internal institutions of the firm favor the executive vis-à-vis shareholders--both as a determinant of taxable income and as a determinant of the elasticity of taxable income (interactive effect). Towards this end, we include the socalled E index proposed by Bebchuk, Cohen, and Ferrell (2008), which is a categorical variable ranging, in ascending (descending) order in which the institutions of the firm favor executives (shareholders), from 0 to 6 based on the number of takeover defense provisions in place. ${ }^{24}$ The GIM index, developed by Gompers, Ishii, and Metrick (2003), follows a similar methodology, using an additional eighteen (thus, twenty-four in total) defense provisions, which are closely

\footnotetext{
${ }^{23}$ The assumptions concerning ISOs and excluding firms with fiscal years not ending in December pertain to all studies cited here. Typically, firms have fiscal years not ending in December to avoid having accounting deadlines coincide with periods of high business activity (e.g., retail sales). As far as we know, no studies have attempted to assess or remedy this shortcoming.

${ }^{24}$ The six provisions include (1) staggered boards (directors are elected in overlapping terms, rather than simultaneously), (2) limitation on shareholders' ability to amend corporate bylaws through majority voting, (3) limitation on shareholders' ability to amend the corporate charter, (4) supermajority shareholder vote to approve a merger, (5) golden parachute (severance agreement providing benefits to executive in event of firing or change of control), and (6) poison pill (shareholder right that renders the company unattractive to a potential acquirer).
} 
related to the provisions included in the E index, but also including six state laws related to corporate governance. ${ }^{25}$ The GIM index and, more recently, the E index have been extensively used and it has been empirically demonstrated that shareholder rights are positively related to higher firm value, higher profits, higher sales growth, and lower capital expenditures. The role of institutions in the response of taxable income to changes in the net-of-tax rate, however, have not been explored.

\subsection{Summary Statistics}

Starting in 2006, the reporting of several Execucomp variables changed significantly and, starting in 2007, the variables needed to create the GIM and E index were no longer collected. Thus, we use data spanning from 1992 to 2005 (the limitation is not particularly unfavorable because there were no major changes in the federal tax code after 2004). ${ }^{26}$ Before imposing any qualifications, the data contain 71,912 executive-year observations. After eliminating executives with permanent income below $\$ 400,000$, at firms with fiscal years not ending in December, at firms without E Index data, or missing state residency data (therefore, we cannot assign a marginal tax rate), reduces the sample to 31,297. Executives are observed in the sample for 8 years on average, with a standard deviation of 3.7 years.

Table (1) reports summary statistics by $E$ Index quartiles. ${ }^{27}$ The average taxable income in the sample is $\$ 2.4$ million and the median taxable income is $\$ 989,000$, indicating that the distribution is highly skewed. The relationship between $E$ Index and taxable income appears negative--the lowest E Index quartile (first quartile) has the highest average taxable income (\$3.3 million), whereas the highest (fourth quartile), and second highest (third quartile), quartiles have the lowest average taxable income (approximately \$2 million). The median taxable income, however, exhibits markedly less variation across E Indices ( $\$ 1.5$ million is the maximum, whereas $\$ 0.91$ is the minimum). Table (1) also reports firm attributes by $E$ Index

\footnotetext{
${ }^{25}$ See Gompers, Ishii, and Metrick (2003), Appendix 1 for a description of all of the provisions.

${ }^{26}$ The data necessary to create the GIM and E index are only available for the years 1993, 95, 98, 00, 02, 04, and 06. We use lagged variables in missing years, except for 1992 and 1997 we use 93 and 98 data, respectively. The results are robust to using only non-imputed values; however, the long-run elasticity of taxable income cannot be estimated without continuous years. This is further discussed in the robustness checks.

${ }^{27}$ We use quartiles rather than indices because several indices have very few observations (less than 1 percent of observations have E Index equal to six). E Index quartiles correspond to E Indices 0-1 (7,712 observations), 2 (7238 observations), 3 (8957 observations), and 4-6 (7390 observations).
} 
quartiles. The relationship between the $E$ Index and firm size is clearly negative--the average market value of the lowest $E$ Index quartile is more than four times greater than the market value of the highest E Index quartile. The median values display less variation across quartiles, indicating that, similar to taxable income, the distribution of market value is highly skewed. The market-to-book ratio is also positively related to a firm's E Index, indicating that firms with lower $E$ Indices have greater growth potential than firms with higher $E$ Indices.

\subsection{Regression Analysis}

The standard specification to estimate the elasticity of taxable income takes the form

$$
\ln \left(\text { Income }_{i, t}\right)=\alpha_{i}+\beta \ln \left(1-\tau_{i, t}\right)+X_{i, t}^{\prime} \Gamma+\varepsilon_{i, t}
$$

where $i$ indexes executives and $t$ indexes time. The variable $\alpha_{i}$ represents executive-firm fixed effects, $X_{i, t}$ represents firm-specific variables (market value, sales, leverage, and marketto-book ratio in the previous period) and a time trend, and $\varepsilon_{i, t}$ represents a random component. The variable $\left(1-\tau_{i, t}\right)$ represents the net-of-tax rate, where $\tau_{i, t}$ is the maximum combined federal and state marginal tax rate. The estimated coefficient $\beta$, therefore, represents the elasticity of taxable income. We add to the standard specification by controlling for firm-specific institutions (the $E$ Index) and interacting institutions with the net-of-tax rate. That is, we estimate the following baseline specification

$$
\ln \left(\text { Income }_{i, t}\right)=\alpha_{i}+\sum_{E_{j} \in \mathrm{E}} \beta_{j}\left(\ln \left(1-\tau_{i, t}\right) \times I\left\{E_{i, t} \in E_{j}\right\}\right)+\sum_{E_{j} \in \mathrm{E}} \delta_{j} I\left\{E_{i, t} \in E_{j}\right\}+X_{i, t}^{\prime} \Gamma+\varepsilon_{i, t}
$$

where $I\left\{E_{i, t} \in E_{j}\right\}$ is an indicator variable equal to 1 if the executive belongs to a firm with an $E$ Index belonging to the $E_{j}$ quintile and 0 if otherwise. ${ }^{28}$ Recall, the $E$ Index is increasing in

\footnotetext{
${ }^{28}$ We use dummy variables for E Index because there is no, a priori, reason the relationship should be linear, nor should we rule out a non-monotonic relationship.
} 
the degree in which the institutions of the firm are pro-executive. The coefficient $\beta_{j}$, therefore, represents the elasticity of taxable income for an executive belonging to a firm with E Index quantile $E_{j}$. The baseline model uses $\mathrm{E}$ Index quartiles (identical to summary statistics). ${ }^{29}$

\subsubsection{Regression Results}

Table (2) reports the regression results for estimating the elasticity of various forms of compensation with respect the net-of-tax rate. Henceforth, "specification" refers to empirical specifications corresponding to columns in the tables (not equation numbers). Specification (1) estimates the standard specification, without controlling for E Index quartiles. The estimated (short-run) elasticity of taxable income for the entire sample is 2.55 , and is significant at the 1 percent confidence level. Specification (2) indicates that the elasticity of income varies significantly across E Index quartiles--the elasticity of the lowest quartile is 1.55 , whereas the elasticity of the highest quartile is 3.32. Moreover, the relationship between the elasticity of taxable income and E Index quartiles appears to be monotonically increasing. A Wald-type test rejects the null hypothesis that the elasticity of first (lowest) quartile is equal to the elasticity of the second quartile ( $p$-value=0.051) and that the elasticity of third quartile is equal to the elasticity of the fourth quartile ( $p$-value $=0.057) .{ }^{30}$ That the elasticity of the first quartile is equal to elasticity of fourth quartile is strongly rejected at all confidence levels ( $p$-value $=0.0002$ ).

The elasticity of other forms of compensation follow a similar pattern as taxable income, although varying in magnitude as expected. In particular, the dependent variable Total Pay, which includes taxable income and Other (non-taxable) compensation, are similar to the estimates for the elasticity of taxable income. As expected, the elasticity of Salary and Bonus (Cash) compensation is relatively small compared to the elasticity of exercised stock options (Options), which is quite large. As mentioned, non-performance-based compensation (including Salary and Bonus) in excess of \$1 million cannot be deducted from corporate profits, thus

\footnotetext{
${ }^{29}$ That is, $E_{j} \in \mathrm{E} \equiv\{\{0,1\}, 2,3,\{4,5,6\}$

${ }^{30} \mathrm{Also}$, we can reject that the elasticity of the first quartile is equal to the elasticity of third quartile (p-value=0.028) and that the elasticity of the second quartile is equal to the elasticity of fourth quartile ( $p$-value $=0.040$ ), but obviously cannot reject that the elasticity of the second quartile is equal to the elasticity of the third quartile.
} 
marginal increases in compensation are typically incentive-based pay (predominately options), reflecting their relative tax advantage.

As pointed out by Goolsbee (2000) and Hall and Liebman (2000), contemporaneous responses to the net-of-tax rate may represent income shifting rather than "permanent" responses. Using the contemporaneous and future net-of-tax rate is the standard approach to allowing individuals to anticipate as well as react to tax changes. ${ }^{31}$ If anticipation is important then the forward net-of-tax rate should be negatively related to current taxable income; that is, future tax increases should increase current taxable income. The sum of the short-run (contemporaneous) and the anticipation elasticity represents the long-run (or at least nontransitory) response to the net-of-tax rate. Certainly this is an important consideration to explore here--it may be that pro-executive institutions (higher E Index) only afford greater discretion in the timing, rather than level, response to changes in the net-of-tax rate.

Specification (6) demonstrates that the non-transitory elasticity is significantly smaller than the contemporaneous elasticity. The estimated non-transitory elasticity is 0.508 and we cannot reject the null hypothesis that the elasticity is equal to zero ( $p$-value=0.1336). Similar to specification (2), specification (7) estimates the contemporaneous and anticipatory elasticities by $E$ Index quartiles. The results indicate that the anticipatory elasticities are remarkably similar for all quartiles; however, the contemporaneous elasticities remain larger for higher quartiles. While the non-transitory elasticity for the three lowest quartiles are not significantly different from zero, the non-transitory elasticity of the highest quartile is quite large $(0.808)$ and significant $(p$-value $=0.083) .^{32}$

The results are even more pronounced when we employ the federal, rather than statespecific, net-of-tax rates, which are reported in specification (8). Using federal tax rates entails losing fewer variables and overcomes possible endogeneity resulting in executives moving across state borders. The non-transitory elasticities for the three lowest quartiles are all

\footnotetext{
${ }^{31}$ Using the forward net-of-tax rate is problematic for a number of reasons; however, we follow the conventional approach because remedying these problems is beyond the scope of this paper. The primary objective is not necessarily to determine precise long-run estimates, but to show that the differences in the short-run elasticities (which are measured more precisely) are not merely a reflection of differences in timing.

${ }^{32}$ Similarly, we can reject the null hypothesis that the elasticity of the lowest quartile is equal to the elasticity of the highest quartile at the 10 percent level.
} 
insignificant; however, the elasticity for the highest quartile is slightly large (0.93) and highly significant $(p$-value $=0.038) .^{33}$

\subsection{Further Evidence: Equity-at-stake}

In this section, we consider the second testable hypothesis of the model--that the elasticity of taxable income is negatively related to an executive's equity-at-stake. ${ }^{34}$ Also in this section, we investigate alternative measures of institutions to corroborate the results in the previous section.

As pointed out by Jensen and Murphy (1990), there are many mechanisms through which value-adding incentives can be achieved; however, the primary mechanisms are ownership of stock and stock options. Following Baker and Hall (2004), we calculate the (equivalent) shares owned from the number of shares and unexercised stock options held by the executive. We refer to the change in executive wealth from all stocks and unexercised stock options held from a $\$ 1000$ change in firm value as the Jensen-Murphy statistic (JMS). Similarly, we refer to the change in executive's wealth from all stocks and unexercised stock options held from a 1 percent change in firm value as Equity-at-stake (EAS). ${ }^{35}$ Table (1) summarizes the JMS and EAS by $E$ Index quartile. For all E Index quartiles, the value of stocks and stock options increases by $\$ 9.58$ on average whenever the value of the firm increases by $\$ 1000$, whereas the median value increases by $\$ 2.35$. Similarly, the average EAS is $\$ 0.20$ and the median is $\$ 0.05$. The median summary statistics for the JMS and EAS by E Index quartiles indicate that there appears to be little relationship between wealth sensitivity and E Index quartiles, and certainly variation within quartiles are more important than variation between quartiles, which suggests that the two testable hypothesis are more or less independent.

We also employ measures of the presence of large institutional investors and the equity

\footnotetext{
${ }^{33}$ Using the federal tax rate as an instrument for state-specific rates yields results similar to (7).

${ }^{34} \mathrm{We}$ focus primarily on the first hypothesis to keep the presentation within reasonable bounds (including various robustness checks), and because the executive's equity-at-stake is, arguably, measured less reliably due to option repricing, short selling, and other types of "unwinding" stock and option risks (Hall and Murphy, 2003), which are unobservable in the data. Moreover, the E Index might also be correlated with actual equity-at-stake--firms with proshareholder institutions may be more effective at aligning the incentives of executives and shareholders.

${ }^{35}$ Whether the Jensen-Murphy Statistic or Equity-at-stake is more important for value-adding incentives depends on whether the marginal product of effort is constant across firm size or increasing with firm size, thus we include both (the former (latter) implies the Jensen-Murphy statistic (Equity-at-stake) is more important).
} 
ownership of the board of directors as alternative measures of the institutions of the firm. In particular, following Hartzell and Stark (2003), we use the Herfindahl-Hirschman Index of institutional ownership concentration, and following Bertrand and Mullainathan (2001), we use the average percentage of shares owned by the board of directors. ${ }^{36}$ Table (1) reports the average percentage of shares owned by the board of directors (\% Board Ownership) and the Herfindahl-Hirschman Index of institutional ownership concentration (Ownership Concentration). The average percent of shares owned by the board of directors is 0.72 percent and the median is 0.2 percent, and is negatively related to E Index quartiles. Similarly, institutional ownership concentration is inversely related to the $E$ Index, although the relationship is quite tenuous using median values.

Similar to (11), we estimate the elasticity of taxable income allowing the elasticity of income, as well as the level of income, to depended on the Jensen-Murphy statistic, Equity-atstake, \%Board Ownership, and Ownership Concentration. Because the variables are continuous, we use both the level and quartiles of each. The generic specification takes the following form ${ }^{37}$

$$
\begin{gathered}
\ln \left(\text { Income }_{i, t}\right)=\alpha_{i}+\beta_{0} \ln \left(1-\tau_{i, t}\right)+\beta_{1}\left(\ln \left(1-\tau_{i, t}\right) \times \operatorname{Index}_{i, t}\right)+\delta\left(\operatorname{Index}_{i, t}\right)+X_{i, t}{ }^{\prime} \Gamma+\varepsilon_{i, t} \\
\ln \left(\text { Income }_{i, t}\right)=\alpha_{i}+\sum_{j=1}^{4} \beta_{j}\left(\ln \left(1-\tau_{i, t}\right) \times I\left\{Q_{i, t} \in Q_{j}\right\}\right)+\sum_{j=1}^{4} \delta_{j} I\left\{Q_{i, t} \in Q_{j}\right\}+X_{i, t}{ }^{\prime} \Gamma+\varepsilon_{i, t}
\end{gathered}
$$

where the variable "Index" represents the continuous form of each variable and $Q_{j}$ represents quartile dummies (e.g., I $\left\{Q_{i, t} \in Q_{1}\right\}$ if the variable for individual $i$ at time $t$ is less than the first quartile of the distribution).

Table (3) reports the results of estimating (12) and (13). The dependent variable is taxable income (Income) in all specifications. For clarity, we henceforth use the term wealth-atstake to represent both JMS and EAS. Specifications (1) and (3) control for the JMS and EAS, respectively, using the variables as continuous indices. Both specifications indicate that the

\footnotetext{
${ }^{36}$ Bertrand and Mullainathan (2001) use a slightly different variable--the number of blocks of at least 5 percent, which is not readily available in our dataset.

${ }^{37}$ Rather than introduce superfluous notation, we import the notation used in (??). Keep in mind we are abusing notation because the estimated coefficients are obviously not identical across model specifications.
} 
executive's wealth-at-stake is inversely related to the elasticity of taxable income. A one standard deviation increase in the JMS and EAS correspond to a decrease in the elasticity of taxable income by 0.28 and 0.34 , respectively. Moreover, the elasticity of taxable income is approximately 1.57 and 1.60 at the median JMS and EAS, respectively.Specifications (2) and (4) control for the JMS and EAS using quartile dummies. Specifications (2) and (4) corroborate that an executive's wealth-at-stake is inversely related to the elasticity of taxable income. Executives with the least wealth-at-stake respond the most to changes in the net-of-tax rate, whereas executives with the most wealth-at-stake respond very little, if at all.Thus, the results are consistent with the predictions of the model--executives with more equity-at-stake respond less to changes in the net-of-tax rate. ${ }^{38}$

Similar specifications are employed for analyzing the role of the average percent of shares owned by the board of directors (\% Board Ownership) and the Herfindahl-Hirschman Index of institutional ownership concentration (Ownership Concentration). Specification (5) indicates that the percent of shares owned by the board of directors is negatively associated with the elasticity of taxable income and is significant at all confidence levels. The elasticity of taxable income at the median percent of shares owned is approximately 2.3 and the elasticity decreases by 0.7 for a one standard deviation increase in the percent of shares owned. Similarly, specification (7) indicates that institutional ownership concentration is negatively associated with the elasticity of taxable income and is significant at the 5 percent confidence level. The elasticity of taxable income at the median concentration index is approximately 1.79 and the elasticity decreases by 0.19 for a one standard deviation increase in ownership concentration. Using quartiles results in estimates similar to the baseline model.

\subsection{Robustness Checks}

Next, we demonstrate that the results are robust with respect to particular modeling assumptions using obvious variations to the baseline model. First we show that the results are not sensitive to using various quantile groups, besides the four quartiles used in the baseline

\footnotetext{
${ }^{38} \mathrm{We}$ also allow income and the elasticity of income to depend on both the executive's E Index and his wealth-atstake simultaneously (not reported). The point estimates of the elasticity by E Index quartiles are mostly unchanged $(1.1,2.0,2.6$, and 3.4) and are significant at the 1 percent level (except the first quartile is significant at the 5 percent level). However, the JMS and EAS are insignificant due to collinearity.
} 
model. ${ }^{39}$ Table (4) demonstrates that the elasticity of taxable income is monotonically increasing in E Indices using various quantile groups. That is, variation within quartiles are consistent with variation between quartiles. Specification (4) indicates that, using six quantiles, the income of the lowest sextile does not exhibit an elasticity significantly different from zero, whereas the income of the highest sextile exhibits a markedly elastic response.

Second, we show that the results are consistent using the GIM index. We employ the GIM index using both quartiles (specification (5)) and as a continuous index (specification (6)). Similar to the baseline model, the estimates for the second and third quartiles are not statistically different from each other, but we can reject that the elasticity of the first and fourth quartiles are equal at all confidence levels ( $p$-value=0.000). Specification (6) indicates that a one point increase in the GIM Index corresponds to an increase in the elasticity of income by approximately 0.3 (similarly a one standard deviation increase in the GIM Index corresponds to an increase of in elasticity by approximately 0.8 ). Or equally, the elasticity of income for an executive with a GIM Index one standard deviation above (below) the mean is 3.05 (1.47).

Table (5) performs a number of further robustness checks. Specification (2) uses a quadratic polynomial time trend. ${ }^{40}$ Specification (2) controls for year fixed effects, which eliminates all variation in federal tax rates and is, therefore, typically not employed in related studies. ${ }^{41}$ Nevertheless, the results still show consistent variation across $E$ Index quartiles. Specification (3) uses only non-imputed E Indices and specification (4) uses only executives with four or more years of data. ${ }^{42}$ Specification (5) uses a similar set of firm-controls as Goolsbee

\footnotetext{
${ }^{39}$ The partitions were chosen to form the most balanced blocks that are collectively exhaustive and mutually exclusive. 2-Groups represents the partition $\{\{0,1,2\},\{3,4,5,6\}\}$, 3-Groups represents $\{\{0,1,2\}, 3,\{4,5,6\}\}$ 5-Groups represents $\{\{0,1\}, 2,3,4,\{5,6\}\}$ and 6-Groups represents $\{0,1,2,3,4,\{5,6\}\}$. We do not use the 7 groups because less than one percent of the sample has $E$ index equal to six.

${ }^{40}$ The results are robust using a cubic polynomial as well (not reported).

${ }^{41}$ All other studies use a linear time trend and do not control for year fixed-effects, except where it is possible to identify variation in the tax rate within years (e.g., comparing the top tax bracket with the second highest tax bracket). But that is not possible here because almost all of the sample is in top bracket.

${ }^{42}$ Excluding executives with limited years of data possibly introduces a survivorship bias as opposed to an attrition bias.
} 
(2000), which includes return on assets and market value. Specification (6) uses the baseline model firm controls, the Goolsbee (2000) firm controls, and return on equity. We also allow for the slopes of the firm-specific control variables to depend on E Index quartiles by interacting all of the firm-specific controls with $E$ Index quartile dummies (not reported). ${ }^{43}$ All of the results presented in Table (5) corroborate that the elasticity of taxable income is positively related to the internal institutions of the firm.

\subsection{Evidence of Rent-seeking}

As mentioned, the theoretical model represents one possible pay-setting framework such that the empirical results demonstrated above can be interpreted as manifestations of rent-seeking. However, it is possible that explanations precluding rent-seeking might generate similar predictions. The question of whether explanations focusing only on the behavioral response of effort can explain the empirical findings is an open question. Prima facie, the conventional approach, however, seems to predict the opposite. As pointed out (Bertrand and Mullainathan, 2001), better governed firms are more capable of implementing contracts with greater pay-forperformance; thus, if executives equate the marginal cost with the marginal benefit of performance then executives at better governed firms should have higher, rather than lower, responses to tax changes. Similarly, conventional approaches might predict that executives would be more, rather than less, inclined to increase effort, and therefore income, as the netof-tax rate increases when they own a greater share of the firm (greater equity-at-stake). Of course, equity-at-stake might also be highly correlated with unobserved wealth, leading to perhaps ambiguous predictions.

Another concern is that the particular variables used as measures of the internal institutions of the firm and the executive's equity-at-stake are significant as a consequence of correlation with other variables (omitted variable bias). For example, the elasticity of income might be associated with firm size or the level of income for reasons unrelated to rent-seeking. For example, previous studies have found that taxable income and the elasticity of income are

\footnotetext{
${ }^{43}$ Estimating separate models for each E Index quartile is, however, not robust due to the significant loss in degrees of freedom.
} 
positively related (Goolsbee, 2000) and firm size is positively related to the marginal product of labor (Rosen, 1981) and therefore the elasticity of income, under some assumptions. ${ }^{44}$ The observation that the E Index is negatively associated with income and firm size (Table 1), however, suggests that one might expect a positive association between pro-shareholder institutions and the elasticity of income. Instead, we find that pro-executive institutions are positively associated with the elasticity of income, consistent with predictions entailing rentseeking. Finally, we employ several measures of institutions, which vary significantly within $\mathrm{E}$ Index quartiles, to reduce the possibility that the results are a consequence of correlation with other variables.

\section{Conclusion}

A longstanding and growing literature maintains that executives are afforded discretion in obtaining rents from within the firm. Whether the degree in exercising this discretion responds to tax policy is, however, not considered in the economic analysis of tax policy. To shed light on whether rent-seeking represents an important behavioral response to changes in tax policy, we propose a simple model of executive income where effort and rent-seeking are determined endogenously. The model shows that rent-seeking, as well as effort, responds to changes in the net-of-tax rate. Moreover, the model generates two testable empirical hypotheses which, under the assumptions of the model, are manifestations of tax policy influencing rent-seeking.

Consistent with the predictions of the model, we find that the elasticity of taxable income is significantly associated with the internal institutions of the firm and the executive's equity-at-stake. In particular, using the so-called E Index proposed by Bebchuk and Fried (2008), we find that the long-run elasticity of taxable income with respect to the net-of-tax rate for executives at firms with institutions most favorable to shareholders is close to perfectly inelastic, whereas the elasticity for executives at firms with institutions most favorable to executives is highly elastic (between 0.8 and 0.9 ) and significant at the 10 and 5 percent confidence levels, respectively. The prediction that the elasticity of taxable income is negatively related to the executive's equity-at-stake is also supported empirically. Finally, the results are

\footnotetext{
${ }^{44}$ The former a consequence of firm size being a determinant of the marginal product of effort (i.e., actions are "chain-letter like") and the latter a consequence of greater income conferring more avenues in which to shift and/or avoid taxable income.
} 
robust using several measures of institutions and equity-at-stake.

While the empirical results are consistent with the predictions, we cannot necessarily rule out all alternative interpretations. Because we cannot disentangle income derived from value-added activities and rent-seeking, all hypothesis derived from models entailing rentseeking are necessarily joint hypotheses, with the underlying assumption that rent-seeking is an important response. Future studies should, therefore, investigate the actual behavioral responses to changes in tax policy, not just the response of income, or explore further indirect testing. Another indirect test might entail investigating the performance of firms corresponding to changes in tax policy. The framework proposed here suggests that the performance of firms following changes in tax policy should depend on both the institutions of the firm and executives' equity-at-stake. We have not investigated this prediction, but future research might explore this question.

Finally, we return to the question of the implications that follow from the observation that rent-seeking responds to tax policy. As pointed out Hall and Liebman (2000), executives manage assets worth billions of dollars and the incentives executives face, which are shaped by tax policy, are of substantial importance to the performance of the US economy as well as government revenue. Understanding whether tax policy influences rent-seeking is, therefore, crucial as the efficiency gains associated with tax cuts may be far less than expected, perhaps even negative.

\section{References}

Lucian Bebchuk and Jesse Fried. Pay without Performance: The Unfulfilled Promise of Executive Compensation. Harvard University Press, November 2004.

Lucian Bebchuk, Alma Cohen, and Allen Ferrell. What Matters in Corporate Governance? Review of Financial Studies, 22(2):783-827, November 2008.

Aaron S. Edlin and Stefan Reichelstein. Holdups, Standard Breach Remedies, and Optimal Investment. The American Economic Review, 86(3):478-501, 1996. 
Aaron S. Edlin and Joseph Stiglitz. Discouragin Rivals: Managerial Rent-Seeking and Economic Inefficiencies. The American Economic Review, 85(5):1301-1312, 1995.

Carola Frydman and Dirk Jenter. CEO Compensation. Annual Review of Financial Economics, 2(1):75-102, 2010.

Carola Frydman and Raven Molloy. Does tax policy affect executive compensation? Evidence from postwar tax reforms. Journal of Public Economics, 95(11-12):1425-1437, December 2011.

Sanford J. Grossman and Oliver D. Hart. An Analysis of the Principal-Agent Problem. The Economic Journal, 51(1):7-45, June 1983.

Jon Gruber and Emmanuel Saez. The elasticity of taxable income: evidence and implications. Journal of Public Economics, 84(1):1-32, April 2002.

Brian Hall and Jeffrey Liebman. The Taxation of Executive Compensation. National Bureau of Economic Research Working Paper Series, No. 7596, March 2000.

Brian Hall and Kevin Murphy. The Trouble with Stock Options. Journal of Economic Perspectives, 17(3):49-70, 2003.

James Heckman. What Has Been Learned About Labor Supply in the Past Twenty Years? The American Economic Review, 83(2):116-121, 1993.

Bengt Holmstrom. Moral Hazard and Obserability. The Bell Journal of Economics, 10(1): 74-91, 1979.

Michael Jensen. Agency Costs of Free Cash Flow, Corporate Finance, and Takeovers. The American Economic Review, 76(2):323-329, 1986. 
Michael Jensen and William Meckling. Theory of the Firm: Managerial Behavior, Agency Costs and Ownership Structure Theory of the Firm. Journal of Financial Economics, 3(4): 305-360, 1976.

Frank H. Knight. Risk, Uncertainty and Profit. New York: Hart, Schaffner, and Marx; repr (1965). Harper and Row, New York., November 1921.

Camelia Kuhnen and Jeffrey Zwiebel. Executive Pay, Hidden Compensation and Managerial Entrenchment. SSRN Electronic Journal, 2009.

N Gregory Mankiw, Matthew Weinzierl, and Danny Yagan. Optimal Taxation in Theory and Practice. Journal of Economic Perspectives, 23(4):147-174, 2009.

James Mirrlees. The Optimal Structure of Incentives and Authority within an Organization. The Bell Journal of Economics, 7(1):105-131, 1976.

Kevin Murphy. Executive Compensation. Handbook of Labor Economics, 3:2486-2563, 1999.

Eissa Nada and Seth Giertz. Trends in High Incomes and Behavioral Responses to Taxation: Evidence from Executive Compensation and Statistics of Income Data. Munich Paper No. 17604, December 2006.

Canice Prendergast. The Provision of Incentives in Firms. Journal of Economic Literature, 37(1):7-63, 1999.

Nancy L Rose and Catherine Wolfram. Regulating Executive Pay : Using the Tax Code to Influence Chief Executive Officer Compensation. Journal of Labor Economics, 20(2): 138175, 2002. 
Sherwin Rosen. The Economics of Superstars. American Economic Review, 71(5):845-58, 1981.

Emmanuel Saez, Joel Slemrod, and Seth Giertz. The Elasticity of Taxable Income with Respect to Marginal Tax Rates : A Critical Review. Journal of Economic Literature, 50(1):3$50,2012$.

Andrei Shleifer and Robert Vishny. Managment Entrenchment: The Case of ManagerSpecific Investments. Journal of Financial Economics, 25:123-139, 1989.

Matti Tuomala. Optimal Income Tax and Redistribution. Oxford University Press, USA, July 1990.

\section{Mathematical Appendix}

\section{First order conditions}

Optimality implies $\{w, q, \theta\}$ satisfies the following

$$
\{w, q, \theta\} \in \operatorname{argmax}\left\{\frac{(1-\tau)(w+\mu r)-b(g) e(q)-a(g) c(\theta)+F[\cdot] V^{u}}{\rho+F[\cdot]}\right\}
$$

This implies the Karush-Kuhn-Tucker conditions (along with complementary slackness condition for non-negativity constraints).

$$
\begin{gathered}
V^{E}-\max _{q, \theta}\left\{\frac{\left((1-\tau)(1-\mu)+f(\cdot) V^{u}\right)(\rho+F[\cdot])}{f(\cdot)}\right\} \leq 0 \\
V^{E}-\max _{w, \theta}\left\{\frac{\left(b(g) e^{\prime}(q)+\mu(1-\tau)+f(\cdot) V^{u}\right)(\rho+F[\cdot])}{f(\cdot)}\right\} \leq 0
\end{gathered}
$$




$$
V^{E}-\max _{w, q}\left\{\frac{\left(a(g) c^{\prime}(\theta)+f(\cdot) V^{u}\right)(\rho+F[\cdot])}{f(\cdot)}\right\} \leq 0
$$

Equations (15), (16), and (17) hold with equality for interior solutions of $w, q$, and $\theta$ respectively. The optimality conditions follow from inspection. 
Table 1: Variable Descriptions

\begin{tabular}{|c|c|c|}
\hline Variable & Description & Source \\
\hline Iolal I’ay & $\begin{array}{l}\text { Salary I Bonus I Restricted Stock Grants I LIIP' Payouts - Valuc } \\
\text { of Options Fxoreised + All Othor Compensation }\end{array}$ & Exccucoinp \\
\hline Inconuc & $\begin{array}{l}\text { Total taxable incone: Salary Bonus I Restricted Stock Grants } \\
\text { ITIP Payouts - Valuo of Options Fxorcised }\end{array}$ & Exccucomp \\
\hline Cash & Salary Bonus & Exccucomp \\
\hline Options & Value of options exercised & Fxconcomp \\
\hline $\begin{array}{l}\text { Other Compen- } \\
\text { sation }\end{array}$ & $\begin{array}{l}\text { Compensation not counted clsewhere and is predominately nontax- } \\
\text { able (Goolsbec, 2000), inclucling severanee peynents, signing bonuscs: } \\
401 \mathrm{~K} \text { contributions, among others. }\end{array}$ & Exccucomp \\
\hline $\begin{array}{l}\text { Jensen-Murpiy } \\
\text { Statistic }\end{array}$ & $\begin{array}{l}\text { Change in the value of the exesutive's portfolio of stocks and stock } \\
\text { options from a } \$ 1000 \text { change in firm value. The value of the cxecutive's } \\
\text { portfolio is caleulated by arlding the number of shares owned and the } \\
\text { number of (cxercisable and unexercisable) unexercised, in-the-moncy } \\
\text { options. the latter multiplied by } 0.7 \text { following Baker and Hall (2004) } \\
\text { to convert options to share-equivalents. }\end{array}$ & Excouconnp \\
\hline Equity-at-stako & $\begin{array}{l}\text { Change in the value of the excentive's portfolio of stocks and stock } \\
\text { options from a } 1 \% \text { change in firm value (see above for calculation of } \\
\text { portfolio value). }\end{array}$ & Exconconnp \\
\hline Market Value & Price-Anmual Close $\times$ Outstanding Shares & Compustat \\
\hline Sules & Sales & Coiripustat \\
\hline Lcverage: & Total Liabilitios / Assots & Compustat \\
\hline Market-to-Book & Price-Annual Close/ Book Value per share & Conpustat \\
\hline Rotiurn on Assots & Not Income before extra. itoms and disc. operations / Total Asscts & Compustat \\
\hline $\begin{array}{l}\text { \%Board Ownor- } \\
\text { ship }\end{array}$ & $\begin{array}{l}\text { Average nurmber of shares owned by board directorsas at percent of all } \\
\text { shares ontstanding. }\end{array}$ & RiskMetrics \\
\hline Owncrship Conc. & Herfandal Index of institutional investor ownership concentration. & Thomas Reuters \\
\hline Fin Index & $\begin{array}{l}\text { Catcgorical index of firm "entrenchment", ranging from } 0 \text { to } 6 \text {, in } \\
\text { descendling order of slarcholder rights (ascending order of execulive } \\
\text { power). Sen section (3.3) for more details. }\end{array}$ & Iucian Bebchuk ${ }^{n}$ \\
\hline GIM Index & $\begin{array}{l}\text { Catcgorical index of firm "governance" constructed by Compers, Ishii, } \\
\text { and Metrick (2003). ranging from 0-24, in desecnding order of sharc- } \\
\text { holder rights. See section (3.3) for more details. }\end{array}$ & RiskMetries \\
\hline $\begin{array}{l}\text { Net-of-trx rate } \\
(1-\tau)\end{array}$ & $\begin{array}{l}\text { Maximum tax rate (total fecleral and state) for an adelitional } \$ 1000 \\
\text { of income on an initial } \$ 1,500,000 \text { of wage income The taxpayer is } \\
\text { assiunod to be married and filing jointly. A mortgage interest dexluc- } \\
\text { tion of } \$ 150,000 \text { and the calculated state income tax are present as } \\
\text { persemal deduetions. }\end{array}$ & TAXSIM ${ }^{b}$ \\
\hline
\end{tabular}

"Data from Bebchuk; Cohen; and Ferrell; "What Matters in Corporate Governance?" The Review of Financial Studies, Vol. 22 (2), 2008. Downloadod Mar. 2012 (http:/ www.law harvard.celu/fauculty/bebchuk/data.shtunl)

${ }^{b}$ Feenherg; Daniel Richard, and Elizabeth Coutts, An Introduction to the TAXSIM Model, Journal of Policy Mualysis and Managenent vol 12 no 1. Winter 1993, pages 189-194. (hitp://www.nber.org/ iaxsin). See (http://www.nber.org/ thaxsim/state-rates/) for a description of the simulation used. 
Table 2: Summary Statistics by Entrenchment index (1992-2005): mean (top row) and median (bottom row) values

\begin{tabular}{|c|c|c|c|c|c|}
\hline F Index Quartile & All & 1 & 2 & 3 & 1 \\
\hline$\div$ Observations & 31,297 & 7,712 & 7,238 & 8,957 & 7,390 \\
\hline & \multicolumn{5}{|c|}{ Fxocutive Compensation } \\
\hline \multirow[t]{2}{*}{ Total Pry (x1000) } & 2,938 & 3,984 & 2,973 & 2,411 & 2,453 \\
\hline & 1,217 & 1,428 & 1,238 & 1,129 & 1,153 \\
\hline \multirow[t]{2}{*}{ Income $(x 1000)$} & 2.442 & 3,342 & 2,456 & 1,991 & 2,034 \\
\hline & 989 & 1,151 & 1,015 & 903 & 950 \\
\hline \multirow[t]{2}{*}{ Cish $(x 1000)$} & 1.050 & 1,278 & 1,051 & 929 & 957 \\
\hline & 722 & 829 & 735 & 673 & 693 \\
\hline \multirow[t]{2}{*}{ Options Excrcised (x1000) } & 1.365 & 2,054 & 1,394 & 1.026 & 1,027 \\
\hline & 96 & 111 & 102 & 90 & 88 \\
\hline \multirow[t]{3}{*}{ Othor Componsation (x1000) } & 169 & 208 & 165 & 115 & 160 \\
\hline & 32 & 32 & 30 & 32 & 35 \\
\hline & \multicolumn{5}{|c|}{ Exccutive Wealth Sensitivity } \\
\hline \multirow[t]{2}{*}{ Jensen-Murphy Statistic } & 9.58 & 12.17 & 9.78 & 7.80 & 8.90 \\
\hline & 2.35 & 2.13 & 2.43 & 2.30 & 2.48 \\
\hline \multirow[t]{2}{*}{ Equity-at-stako: } & 0.203 & 0.257 & 0.207 & 0.165 & 0.188 \\
\hline & 0.051 & 0.047 & 0.053 & $0.0 \overline{5} 1$ & 0.054 \\
\hline \multirow{3}{*}{ M[arket value: ( $\mathrm{x} 1 \mathrm{mi}$ ]) } & \multicolumn{5}{|c|}{ Firm Financials } \\
\hline & 13,823 & 28,721 & 12,694 & 8,145 & 6,269 \\
\hline & 3.750 & 5,626 & 3,710 & 3.619 & 2,966 \\
\hline \multirow[t]{2}{*}{ Murket-to-Book } & 3.17 & 3.65 & 3.39 & 2.87 & 2.80 \\
\hline & 2.40 & 2.55 & 2.57 & 2.38 & 2.22 \\
\hline \multirow[t]{2}{*}{ Levorage: } & 0.63 & 0.62 & 0.61 & 0.61 & 0.66 \\
\hline & 0.63 & 0.63 & 0.61 & 0.62 & 0.66 \\
\hline \multirow[t]{2}{*}{ Return on Assets } & 4.35 & 3.87 & 4.27 & 4.84 & 4.35 \\
\hline & 4.10 & 3.66 & 4.51 & 4.26 & 3.89 \\
\hline \multirow{3}{*}{$\%$ Board Ownership } & \multicolumn{5}{|c|}{ Firn Governfunce! } \\
\hline & 0.72 & 1.06 & 0.81 & 0.51 & 0.37 \\
\hline & 0.20 & 0.27 & 0.23 & 0.20 & 0.17 \\
\hline \multirow[t]{2}{*}{ Ownership Concentration } & 0.057 & 0.071 & 0.055 & 0.052 & 0.049 \\
\hline & 0.044 & 0.046 & 0.042 & 0.044 & 0.043 \\
\hline Governanee (GIM index) & 9.57 & 6.88 & 8.78 & 10.55 & 11.96 \\
\hline
\end{tabular}

Note: Sce lable 1 for a description of variables. Sample includes executives with permancent income greater than $\$ 400,000$ in 2006 LS\$ and at firms with fiscal years encling in December. All prices deflated by the Consumer Price Index in 2006\$. 
Table 3: Elasticity of various forms of compensation with respect to the net-of-tax rate.

\begin{tabular}{|c|c|c|c|c|c|c|c|c|}
\hline Varinbles & $\begin{array}{c}\text { (1) } \\
\text { Income }\end{array}$ & $\begin{array}{c}\text { (2) } \\
\text { Income }\end{array}$ & $\begin{array}{c}\text { (3) } \\
\text { lotal Pay }\end{array}$ & $\begin{array}{c}(4) \\
\text { Cash }\end{array}$ & $\begin{array}{c}(5) \\
\text { Options }\end{array}$ & $\begin{array}{c}\text { (6) } \\
\text { Income }\end{array}$ & $\begin{array}{c}\text { (7) } \\
\text { Income }\end{array}$ & $\begin{array}{c}(8) \\
\text { Income }\end{array}$ \\
\hline$\left(1-\tau_{t}\right)$ & $\begin{array}{c}2.550^{* * *} \\
(0.262)\end{array}$ & & & & & $\begin{array}{c}3.235^{* * \times} \\
(0.329)\end{array}$ & & \\
\hline$\left(1-\tau_{l+1}\right)$ & & & & & & $\begin{array}{c}-2.727^{\text {k }} \text { (0.3 } \\
(0.343)\end{array}$ & & \\
\hline$\left(1-\tau_{l}\right) \times I\left\{L^{\prime} \in L_{1}\right\}$ & & $\begin{array}{c}1.525^{* * * *} \\
(0.407)\end{array}$ & $\begin{array}{c}1.72: 1 * * * \\
(0.371)\end{array}$ & $\begin{array}{c}0.19 \mathrm{~s} \\
(0.268)\end{array}$ & $\begin{array}{c}3.954^{* * *} * \\
(1.022)\end{array}$ & & $\begin{array}{c}2.904^{* * * *} \\
(0.495)\end{array}$ & $\begin{array}{c}2.815^{\text {*w* }} \\
(0.493)\end{array}$ \\
\hline$\left(1-\tau_{t}\right) \times I\left\{\mathrm{E} \in \mathrm{F}_{2}\right\}$ & & $\begin{array}{c}2.373^{* * *} \\
(0.381)\end{array}$ & $\begin{array}{c}2.547^{* * *} \\
(0.348)\end{array}$ & $\begin{array}{c}0.775^{* * *} \\
(0.2 \bar{j} 1)\end{array}$ & $\begin{array}{c}6.128^{* * *} \\
(0.957)\end{array}$ & & $\begin{array}{c}3.212^{* * *} \\
(0.463)\end{array}$ & $\begin{array}{c}3.095 \\
(10.468)\end{array}$ \\
\hline$\left(1-\tau_{l}\right) \times I\left\{E \in E_{3}\right\}$ & & $\begin{array}{c}2 . \overline{1} 14^{* k \times k} \\
(0.351)\end{array}$ & $\begin{array}{c}2.849^{* * * *} \\
(0.320)\end{array}$ & $\begin{array}{c}0.950^{* * * * *} \\
(0.231)\end{array}$ & $\begin{array}{c}7.993^{* * * * *} \\
(0.875)\end{array}$ & & $\begin{array}{c}3.325^{* * * *} \\
(0.430)\end{array}$ & $\begin{array}{c}3.624^{\text {*3** }} \\
(0.424)\end{array}$ \\
\hline$\left(1-\tau_{+}\right) \times I\left\{L^{\prime} \in L_{4}^{\prime}\right\}$ & & $\begin{array}{c}3.316^{* * *} \\
(0.376)\end{array}$ & $\begin{array}{c}3.614^{* * *} \\
(0.343)\end{array}$ & $\begin{array}{c}1.363^{* * *} \\
(0.248)\end{array}$ & $\begin{array}{c}7.169^{* * * *} \\
(0.940)\end{array}$ & & $\begin{array}{c}3.661^{* * *} \\
(0.457)\end{array}$ & $\begin{array}{c}1.003^{* * *} \\
(0.444)\end{array}$ \\
\hline$\left(1-\tau_{t+1}\right) \times\left[\left\{\mathrm{F} \in \mathrm{F}_{1}\right\}\right.$ & & & & & & & $\begin{array}{c}-2.865^{* * *} \\
(0.347)\end{array}$ & $\begin{array}{c}-3.082^{* * *} \\
(0.315)\end{array}$ \\
\hline$\left(1-\tau_{\ddagger 11}\right) \times I\left\{E \in E_{2}\right\}$ & & & & & & & $\begin{array}{c}-2.8 \bar{j} 4^{* * * *} \\
(0.347)\end{array}$ & $\begin{array}{c}-3.076^{* * * *} \\
(0.315)\end{array}$ \\
\hline$\left(1-\tau_{t+1}\right) \times\left[\left\{E \in L_{3}\right\}\right.$ & & & & & & & $\begin{array}{c}-2.861^{* * * *} \\
(0.348)\end{array}$ & $\begin{array}{c}-3.076^{\text {*3** }}(0.315)\end{array}$ \\
\hline$\left(1-\tau_{l+1}\right) \times I\left\{E \subset E_{A}\right\}$ & & & & & & & $\begin{array}{c}-2.853^{* * * * *} \\
(0.318)\end{array}$ & $\begin{array}{c}-3.072^{* * * *} \\
(0.315)\end{array}$ \\
\hline $\mathrm{I}\left\{\mathrm{E} \in \mathrm{E}_{2}\right\}$ & & $\begin{array}{c}-3.378^{*} \\
(1.760)\end{array}$ & $\begin{array}{c}-3.268^{* *} \\
(1.607)\end{array}$ & $\begin{array}{l}-2.295^{* * *} \\
(1.160)\end{array}$ & $\begin{array}{c}-9.909^{* * *} \\
(4.423)\end{array}$ & & $\begin{array}{r}-1.209 \\
(2.071)\end{array}$ & $\begin{array}{l}-1.104 \\
(2.414)\end{array}$ \\
\hline $\mathrm{I}\left\{\mathrm{F}_{\mathrm{i}} \in \mathrm{F}_{\mathrm{in}}\right\}$ & & $\begin{array}{c}-3.897^{* k} \\
(1.822)\end{array}$ & $\begin{array}{c}-4.426^{\text {*斿* }} \\
(1.663)\end{array}$ & $\begin{array}{c}-3.007^{* *} \\
(1.201)\end{array}$ & $\begin{array}{c}-16.05^{* * * *} \\
(4.563)\end{array}$ & & $\begin{array}{l}-1.5993 \\
(2.149)\end{array}$ & $\begin{array}{c}-3.177 \\
(2.307)\end{array}$ \\
\hline $\mathrm{I}\{\mathrm{E} \subset \mathrm{E}\}$ & & $\begin{array}{c}-7.073^{\text {k }}(1.947) \\
(1.97\end{array}$ & $\begin{array}{c}-7.470^{\text {*ask }} \\
(1.776)\end{array}$ & $\begin{array}{c}-4.692^{* * * *} \\
(1.281)\end{array}$ & $\begin{array}{c}-12.59^{* k \cdots k} \\
(1.878)\end{array}$ & & $\begin{array}{c}-2.875 \\
(2.289)\end{array}$ & $\begin{array}{l}-4.672^{*} \\
(2.381)\end{array}$ \\
\hline Market Value & $\begin{array}{c}0.398^{* * \times} \\
(0.014)\end{array}$ & $\begin{array}{c}0.399^{* * *} \\
(0.014)\end{array}$ & $\begin{array}{c}0.329^{* * * *} \\
(0.013)\end{array}$ & $\begin{array}{c}\text { C.0737**** } \\
(0.009)\end{array}$ & $\begin{array}{c}0.751^{* * * *} \\
(0.035)\end{array}$ & $\begin{array}{c}0.313^{* * \times} \\
(0.016) \\
\end{array}$ & $\begin{array}{c}0.355 * * * * \\
(0.016)\end{array}$ & $\begin{array}{l}0.313^{* * *} \\
(0.0136) \\
\end{array}$ \\
\hline+ Firm Controls & Yes & Yes & Yes & Yes & Yes & Yes & Yes & Yes \\
\hline Fedcral Tax Rates & No & No & No & No & No & No & No & $\mathrm{Yus}$ \\
\hline Observations & 26.727 & 26,727 & 26,736 & 26,713 & 25,999 & 20.896 & 20.559 & 26,041 \\
\hline \# of Exccutives & 6,063 & 6,063 & 6,063 & 6,0633 & 5,993 & 5,365 & 5,302 & 7,004 \\
\hline R-squared & 0.208 & 0.209 & 0.251 & 0.131 & 0.149 & 0.195 & 0.197 & 0.120 \\
\hline
\end{tabular}

Note: The sample in each regression pertains to 1992-2005, prices in 2006 constant dollars. All estimations contro] for executive-firm f.xed effects and a linear time trend. Income represents total taxable income and includes: Salary - Bonus - Restricted Stock Grants - LIIP Payouts + Value of Options Exercised. Total pay includes Income Other compensation (non-taxnble). Cash represents Sulary - Bonus. Options relers to the value of options exercised. All specifications control for the combined federal and state net-of-tax rate, except aperification (8) uses only federal rates. $\mathbb{I}\left\{\mathrm{L} \in \mathrm{E}_{j}\right\}$ is an indicator variable equal to 1 if the executive-firm:s $\mathbf{E}$ index belongs to the $j$ quartile and 0 if otherwise. Firu Controls includes: Sales, Market-to-Book value, and Leveruge in the previous year. All non-ratio-scale variables, including all forms of compensation, the net-of-tax rate, Harket Value, and Sales, are in log form. Sample includes executives with permanent income greater than $\$ 400,000$ in 2006 LS\$. The

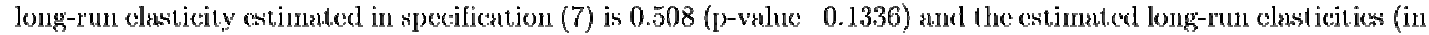
dwocending orelcr of F. quartiks) are $0.039,0.358$ (p-value 0.45 ), 0.464 (p-value 0.291 ), and 0.308 (p-valus: 0.083 ). Standard errors in parentheses (*** $\left.\mathrm{p}<0.01,{ }^{* *} \mathrm{p}<0.05{ }^{*}, \mathrm{p}<0.1\right)$. 
Table 4: Elasticity of taxable income with respect to the net-of-tax rate (dep var: Income).

\begin{tabular}{|c|c|c|c|c|c|c|c|c|}
\hline \multirow[b]{2}{*}{ Independent } & \multicolumn{2}{|c|}{ Jensen-Muphy } & \multicolumn{2}{|c|}{ Equity-at-stake } & \multicolumn{2}{|c|}{$\%$ Board Ownorship } & \multicolumn{2}{|c|}{ Ownership Concontration } \\
\hline & (1) & (2) & (3) & (4) & (5) & (6) & (7) & (8) \\
\hline Variables & Indrex & Qunntilos & Indrex & Quantiles & Index & Quentiles & Index & Quantile: \\
\hline \multirow[t]{2}{*}{$\left(1-\tau_{t}\right)$} & $1.593^{\times * *}$ & & $1.626^{x * *}$ & & $2.361^{* * x}$ & & $1.935^{* \times *}$ & \\
\hline & $(0.003-39)$ & & $(0.237)$ & & $(0.361)$ & & $(0.249)$ & \\
\hline \multirow[t]{2}{*}{ Inclex $\times\left(1-\tau_{t}\right)$} & $-0.00917^{* \times *}$ & & $-0.531 * * x$ & & $-0.370^{* * * *}$ & & $-3.206^{* *}$ & \\
\hline & $(3.439)$ & & $(0.171)$ & & $(0.08 \mathrm{ij} 1)$ & & $(1.527)$ & \\
\hline \multirow[t]{2}{*}{ Iuclex } & $0.0382^{2 * * * *}$ & & $2.195^{\text {s.k* }}$ & & $1.190^{\text {*坐* }}$ & & $12.56^{4 * * *}$ & \\
\hline & $(0.01 \cdot 12)$ & & $(0.691)$ & & $(0.311)$ & & (6.167) & \\
\hline$\left(1-\tau_{t}\right) \times \mathrm{I}\left\{Q \subset Q_{1}\right\}$ & & $\begin{array}{c}2.603^{\neq * *} \\
(0.355)\end{array}$ & & $\begin{array}{c}2.703^{* * *} \\
(0.357)\end{array}$ & & $\begin{array}{c}3.592^{* * *} \\
(0.428)\end{array}$ & & $\begin{array}{c}2.070^{* * *} \\
(0.285)\end{array}$ \\
\hline \multirow[t]{2}{*}{$\left(1-\tau_{l}\right) \times 1\left\{Q \subset Q_{2}\right\}$} & & $1.950^{* * * *}$ & & $2.041^{* * * 8}$ & & $2.035^{\text {3k<* }}$ & & $1.434^{* * *}$ \\
\hline & & $(0.310)$ & & $(0.311)$ & & $(0.427)$ & & $(0.274)$ \\
\hline \multirow[t]{2}{*}{$\left(1-\tau_{t}\right) \times \mathbb{I}\left\{Q \in Q_{3}\right\}$} & & $1.410^{* 2 * * *}$ & & $1.440^{* * * * *}$ & & $0.997^{* * *}$ & & $0.734^{* * *}$ \\
\hline & & $(0.301)$ & & $(0.300)$ & & $(0.440)$ & & $(0.304)$ \\
\hline \multirow[t]{2}{*}{$\left(1-\tau_{l}\right) \times \mathrm{I}\left\{Q \in Q_{A}\right\}$} & & 0.134 & & 0.216 & & 1.013 & & $1.572^{* * *}$ \\
\hline & & $(0.323)$ & & $(0.320)$ & & $(0.494)$ & & $(0.368)$ \\
\hline \multirow[t]{2}{*}{$\mathbb{I}\left\{Q \subset Q_{2}\right\}$} & & $2.650^{7}$ & & $2.701 \%$ & & 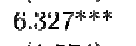 & & $2.458^{* * *}$ \\
\hline & & $(1.388)$ & & $(1.395)$ & & $(1.574)$ & & $(1.093)$ \\
\hline \multirow[t]{2}{*}{$I\left\{Q \in Q_{3}\right\}$} & & $4.764^{\neq-2 *}$ & & $5.085^{* * \ldots}$ & & $10.42^{* * *}$ & & $5.193^{* * *}$ \\
\hline & & $(1.518)$ & & $(1.519)$ & & $(1.747)$ & & $(1.240)$ \\
\hline \multirow[t]{2}{*}{$\mathbb{I}\left\{Q \in Q_{1}\right\}$} & & $9.92 i^{\neq * *}$ & & $10.04^{* * *}$ & & $10.25^{* * *}$ & & 1.782 \\
\hline & & (1.618) & & (1.618) & & $(1.995)$ & & $(1.494)$ \\
\hline | Firm Controls & Yrss & Yos & Yos & Yos & Yos & Yos & $Y \mathrm{ss}$ & $Y(x)$ \\
\hline Ohservations & 34,876 & 34,876 & 34,876 & 34,875 & 20,893 & 20.893 & 33,982 & 33,982 \\
\hline \# of bxcentives & 8.195 & 8,195 & 8.195 & 8,195 & 8,$4 ; 1$ & 8,451 & 7.358 & 7.358 \\
\hline R-squured & 0.183 & 0.182 & 0.183 & 0.185 & 0.148 & 0.148 & 0.205 & 0.199 \\
\hline
\end{tabular}

Note: The sample in each regression pertains to 1992-2005, prices in 2006 constant dollars. All estimations control for executive-firm tixed effects and a linear time trend. The dependent variable is total taxable income, which includes:

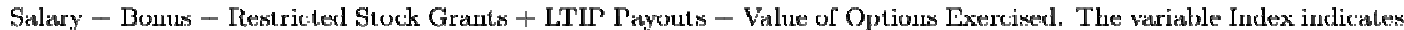
that the independent variables are considered continuous and $\mathrm{I}\left\{Q \in Q_{j}\right\}$ is an inclicator variable equal to $\perp$ if the index is in the $j$ quartile of the distribution and () otherwise. The Jensen-Murphy Index is the change in executive weallh from all stocks and unexercised stock options held from a $\$ 1000$ chenge in firm value. The Equity-at-stake Index is the change in executive wealth from a change of $1 \%$ change in firm value. \% Board Ownership is the average percent of

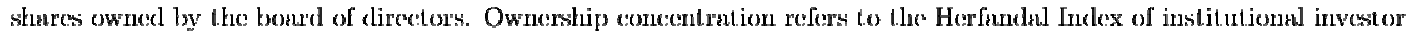
ownership concentration. +Firm Controls includes: Markel Value, Stles, Market-Lo-Book value, rand Leverage. All non-ratio-sctale variables, including all forms of compensation, the net-of-tax rate $(1-\tau)$, Market Vulue; and Sales, are in log form. Sample includes executives with permanent income greater than $\$ 100,000$ in 2006 USS. Standard errors in prarenthoses $(* * * p<0.01, * * p<0.05, * j<0.1)$. 
Table 5: Elasticity of Taxable Income with respect to the net-of-tex rate using various E Index quantiles and the GLM Index

\begin{tabular}{|c|c|c|c|c|c|c|}
\hline Variables & $\begin{array}{c}\text { (1) } \\
\text { 2-Groups }\end{array}$ & $\begin{array}{c}(2) \\
\text { 3-Groups }\end{array}$ & $\begin{array}{c}(3) \\
\text { 5-Groups }\end{array}$ & $\begin{array}{c}\text { (1) } \\
\text { 6-Groups }\end{array}$ & $\begin{array}{c}(\overline{5}) \\
\text { G Index }\end{array}$ & $\begin{array}{c}(6) \\
\mathrm{G} \text { quantiles }\end{array}$ \\
\hline$\left(1-\tau_{t}\right) \times 1\left\{\mathrm{E} \in \mathrm{E}_{1}\right\}$ & $\begin{array}{c}2.070^{* *} \\
(0.326)\end{array}$ & $\begin{array}{c}2.052^{\text {**** }} \\
(0.326)\end{array}$ & $\begin{array}{c}1.528^{25} \\
(0.407)\end{array}$ & $\begin{array}{c}0.543 \\
(0.583)\end{array}$ & & \\
\hline$\left(1-\tau_{\ell}\right) \times I\left\{E \in E_{2}\right\}$ & $\begin{array}{c}2.877^{\text {***3\% }} \\
(0.295)\end{array}$ & $\begin{array}{c}2.496^{* * 3 k} \\
(0.350)\end{array}$ & $\begin{array}{c}2.367^{* * *} \\
(0.381)\end{array}$ & $\begin{array}{c}1.854^{*} \\
(0.450)\end{array}$ & & \\
\hline$\left(1-\tau_{t}\right) \times I\left\{E \in E_{3}\right\}$ & & $\begin{array}{c}3.298^{* * * *} \\
(0.376)\end{array}$ & $\begin{array}{c}2.469^{* * * *} \\
(0.350)\end{array}$ & $\begin{array}{c}2.421^{*} * * \\
(0.381)\end{array}$ & & \\
\hline$\left(1-\tau_{t}\right) \times \mathrm{I}\left\{\mathrm{E} \in \mathrm{E}_{4}\right\}$ & & & $\begin{array}{c}2.573^{* \% *} \\
(0.404)\end{array}$ & $\begin{array}{c}2.506^{* \% *} \\
(0.351)\end{array}$ & & \\
\hline$\left(1-\tau_{t}\right) \times I\left\{E \in E_{5}\right\}$ & & & $\begin{array}{c}6.552^{* 8 *} \\
\left(0.7^{i} 20\right)\end{array}$ & $\begin{array}{c}2.610^{*} \\
(0.405)\end{array}$ & & \\
\hline$\left(1-\tau_{t}\right) \times 1\left\{L \in L_{k}\right\}$ & & & & $\begin{array}{c}6.582^{\text {s. }} \\
(0.720)\end{array}$ & & \\
\hline$\left(1-\tau_{t}\right) \times I\left\{G \in G_{1}\right\}$ & & & & & $\begin{array}{c}1.547^{* * * *} * \\
(0.377)\end{array}$ & \\
\hline$\left(1-\tau_{t}\right) \times 1\left\{\mathrm{G} \in \mathrm{G}_{2}\right\}$ & & & & & $\begin{array}{c}2.400^{-} \text {*** * } \\
(0.340)\end{array}$ & \\
\hline$\left(1-\tau_{t}\right) \times I\left\{G \in G_{i j}\right\}$ & & & & & $\begin{array}{c}2.049^{\text {**3k* }} \\
(0.314)\end{array}$ & \\
\hline$\left(1-\tau_{t}\right) \times 1\left\{\mathrm{G} \in \mathrm{G}_{4}\right\}$ & & & & & $\begin{array}{c}3.603^{* * * *} \\
(0.399)\end{array}$ & \\
\hline$\left(1-\tau_{t}\right)$ & & & & & & $\begin{array}{c}-0.452 \\
(0.633)\end{array}$ \\
\hline$\left(1-\tau_{l}\right) \times($ GIMI Index $)$ & & & & & & $\begin{array}{l}0.294^{* * *} \\
(0.0610)\end{array}$ \\
\hline GIM Indox & & & & & & $\begin{array}{c}-1.181^{* * * *} \\
(0.246)\end{array}$ \\
\hline Finn Controls & Yes & Yos & Yus & Yos & $Y(x)$ & Yes \\
\hline Observations & 26,727 & 26,727 & 26,727 & 26,727 & 29,167 & 29,167 \\
\hline " of Executives & 6,063 & 6.063 & 6,063 & 6,063 & 6,560 & 6,560 \\
\hline R-sc]latchl & 0.208 & 0.208 & 0.210 & 0.210 & 0.200 & 0.200 \\
\hline
\end{tabular}

Note: The sample in each regression pertains to 1992-2005, prices in 2006 constant dollars. All estimations control for exceutive-firm fixed effects and a linear time trend. The dependent variable is taxable income, which includes: Salary + Bonus - Restricted Stock Grants LIIP Payouts + Value of Options Exercised. $I\left\{\left[\in \mathrm{E}_{j}\right\}\right.$ is an indicator variable equal to 1 if the executive-firm's $\mathrm{E}$ index belongs to $j$ quantile and 0 if otherwise. 2-Groups represents E index medians: 3-Groups represcuts E index terciles: and so forth. Similarly. I $\left\{\mathrm{GCG}_{j}\right\}$ is an indicator variable equal to 1 if the executive-firm's GIM index belongs to the $j$ quartile. GIM Index uses the index as a continuous-type variable. -Firm Controls includes: market value, salcs; market-to-book ratio, and levoragc. All non-ratio-scale variables, including all forms of compensation, the net-of-tax rate, market valne, and saler, are in log form. Sumple includes executives with permanent income greater than $\$ 400,000$ in 2006 US\$. Standard errors in parentheses ( ${ }^{* * *} \mathrm{p}<0.01,{ }^{* *} \mathrm{p}<0.05$, $^{*} \mathrm{p}<0.1$ ). 
Table 6: Elasticity of taxable income with respect to the net-of-tax rate robustness checl (dep var: Income).

\begin{tabular}{|c|c|c|c|c|c|c|}
\hline & $\begin{array}{c}\text { (1) } \\
+ \text { Tr'end }^{2}\end{array}$ & $\begin{array}{c}(2) \\
\text { Yoar } \\
\text { Dumnrnies }\end{array}$ & $\begin{array}{c}(3) \\
\text { Restricted } \\
\text { Sample }^{o}\end{array}$ & $\begin{array}{c}(4) \\
\text { Rostrictod } \\
\text { Sample }\end{array}$ & $\begin{array}{c}(5) \\
\text { Goolsbee } \\
\text { Controls: }\end{array}$ & $\begin{array}{c}\text { (6) } \\
\text { All Firm } \\
\text { Controls }\end{array}$ \\
\hline$\left(1-\tau_{t}\right) \times \mathrm{I}\{\mathrm{E}-0-1\}$ & $\begin{array}{c}0.916^{* * *} \\
(0.468)\end{array}$ & $\begin{array}{c}1.835 \\
(1.579)\end{array}$ & $\begin{array}{c}1.153 \\
(0.710)\end{array}$ & $\begin{array}{c}1.170^{* * *} \\
(0.411)\end{array}$ & $\begin{array}{c}1.695^{* * *} \\
(0.406)\end{array}$ & $\begin{array}{c}1.853^{* * * *} \\
(0.397)\end{array}$ \\
\hline$\left(1-\tau_{t}\right) \times I\{E-2\}$ & $\begin{array}{c}1.787^{* x *} \\
(0.117)\end{array}$ & $\begin{array}{l}2.617^{*} \\
(1.578)\end{array}$ & $\begin{array}{c}2.973^{*} * * \\
(0.656)\end{array}$ & $\begin{array}{c}2.350^{* * *} \\
(0.385)\end{array}$ & $\begin{array}{c}2.555^{* 3 * *} \\
(0.381)\end{array}$ & $\begin{array}{c}2.828^{* * * * *} \\
(0.373)\end{array}$ \\
\hline$\left(1-\tau_{t}\right) \times I\left\{\begin{array}{ll}E & 3\end{array}\right\}$ & $\begin{array}{c}1.919^{* * *} \\
(0.423)\end{array}$ & $\begin{array}{l}2.802^{*} \\
(1.564)\end{array}$ & $\begin{array}{c}3.101^{* * * *} \\
(0.603)\end{array}$ & $\begin{array}{c}2.462^{* * *} \\
(0.35 j)\end{array}$ & $\begin{array}{c}2.650^{* * * *} \\
(0.350)\end{array}$ & $\begin{array}{c}2.870^{* * *} \\
(0.342)\end{array}$ \\
\hline$\left(1-\tau_{l}\right) \times I\left\{\begin{array}{ll}E & 4-6\end{array}\right\}$ & $\begin{array}{c}2.720^{* * *} \\
(0.445)\end{array}$ & $\begin{array}{l}3.584^{* *} \\
(1.570)\end{array}$ & $\begin{array}{c}4.465^{* * *} \\
(0.647)\end{array}$ & $\begin{array}{c}3.353^{* * *} \\
(0.380)\end{array}$ & $\begin{array}{c}3.561^{* * *} \\
(0.391)\end{array}$ & $\begin{array}{c}3.393^{* * *} \\
(0.368)\end{array}$ \\
\hline Market Value & $\begin{array}{c}0.397^{* * *} \\
(0.0137)\end{array}$ & $\begin{array}{c}0.382^{* * * *} \\
(0.01 \neq 1)\end{array}$ & $\begin{array}{c}0.471^{*} * * \\
(0.0256)\end{array}$ & $\begin{array}{c}0.405^{*} \text { * } \\
(0.0140)\end{array}$ & $\begin{array}{c}0.300^{* *} * \\
(0.0118)\end{array}$ & $\begin{array}{c}0.397^{\text {***** }} \\
(0.0149)\end{array}$ \\
\hline Return on Assets & & & & & $\begin{array}{c}0.00280^{\text {*3*3 }} \\
(0.0006)\end{array}$ & $\begin{array}{c}\left(0.0035^{\text {*2*3x }}\right. \\
(0.0009)\end{array}$ \\
\hline Returti on Equity & & & & & & $\begin{array}{c}-2.35 \mathrm{e}-05 \\
(0.0002)\end{array}$ \\
\hline Trend & quadratic & n.d. & lincar & linesr & lincar & lincar \\
\hline Year Dummies & No & Yes & No & No & No & No \\
\hline -Firm Controls & Yes & Yes & Yes & Yes & No & Yes \\
\hline Obscrvatiotss & 26,727 & 26.727 & 11.904 & 24,935 & 26,810 & 26,276 \\
\hline \# of lixecuntives & 6.063 & 5,063 & 5486 & 5.831 & 6,066 & 5,992 \\
\hline R-squared & 0.209 & 0.219 & 0.226 & 0.206 & 0.203 & 0.216 \\
\hline
\end{tabular}

Note: The sample in each regression pertains to $1992-2005$, prices in 2006 constant dollars. All estinations control for executive-firm fixed effects and a linear tinne trend. The depenclent variable is total taxable income, which inclurles: Salary - Bomus - Restricted Stock Grants I LTIP Payouts . Value of Options Excreised. "Specification 3 mploys only the ad ual (non-imputed) F Index data. "Specification 4 restricts the sample to executives with at least 4 observation years. ${ }^{C}$ Goolsbec Controls refers to identical firm controls employed in Goolsluee (2000). which includes retum on assets and market value. Specification (6) controls for the bascline firm controls, the Goolsbee controls, and return on equity. Firm Controls includes: nnarket value, salcs, market-lo-book ratio, and leverage. All non-1atioscale variables, including all forms of compensation, the net-of-tax rate, market valne, and salcs; are in $\log$ form. Sumple includes executives with permanent income grealer than $\$ 400,000$ in 2006 USS and at firms with fiscal years ending in Decennler. Stanclard errors in parentheses (*** p $<0.01, * * \mathrm{p}<0.05, * \mathrm{p}<0.1$ ). 